\title{
ÉLALUATION DU BESOIN EN LYSINE IU PORCELET SEVRÉ
}

\author{
J. LOUGNON et A. BRETTE \\ Société de Chimie biologique A. E. C., \\ 03 - Commentry
}

\section{RÉSUMÉ}

Une expérience est réalisée en vue de préciser les besoins en lysine du porcelet sevré. 24 " paires" de porcelets âgés de 6 semaines et pesant en moyenne $12 \mathrm{~kg}$ sont répartis en 3 lots expérimentaux. Les animaux consomment ad libitum (pendant 28 jours) l'un des 3 régimes contenant $0,85,0,95$ ou $\mathrm{r}, 05 \mathrm{p}$. Ioo de lysine. identiques par ailleurs.

La consommation est peu différente d'un lot à l'autre. L'aliment contenant 0,95 p. Ioo de lysine (lot II) assure une vitessc de croissance et une efficacité alimentaire significativement supérieures à celle des animaux recevant les régimes à 0,85 p. Ioo (lot I) ou r,05 p. roo (lot III). Le gain de poids moyen quotidien $(\mathrm{g})$ et l'indice de consommation sont en moyenne les suivants : lot I : 596, 2,II; lot II : 650, I,97; lot III : 6I I, 2,04.

L'aliment II a ure teneur en lysine de 3,0 g par kcal d'énergie digestible, 3,I g par kcal d'énergie métabolisable, 4,5 $\mathrm{g}$ par kcal d'énergie nette. Les porcelets de ce lot II ont ingéré en moyenne $\mathrm{I} I, 8 \mathrm{~g}$ de lysine par jour.

\section{SUMMARY}

\section{ESTIMATION OF THE LYSINE REQUIREMENT OF WEANED PIGLETS}

An experiment was carried out in view to specify the Lysine requirements of weaned piglets. 24 "pairs " of 6 weeks old weighing about $12 \mathrm{~kg}$ were divided into 3 experimental groups (treatments). The animals were fed ad libitum (during 28 days) with one of the 3 diets containing $0.8_{5}, 0.95$ or 1.05 P. I0o Lysine. These diets were similar as for the other components .

The consumption only differed a little from one treatment to another. With the feed containing 0.95 p. 100 Lysine (treatment II), the growth rate and food efficiency were significantly higher than those of the animals fed with diets at 0.85 p. roo (treatment I) or I.05 p. roo lysine (treatment III). On an average, daily mean gain (gram) and the food conversion ratio were as follows :

$$
\begin{aligned}
& \text { - treatment I }: 596,2.1 \mathrm{I} \\
& \text { - treatment II }: 650,1.97 \\
& \text { - treatment III }: 6 \mathrm{II}, 2.04
\end{aligned}
$$

The feed II had a Lysine content of $3.0 \mathrm{~g}$ per kcal. digestible energy, $3 . \mathrm{r} \mathrm{g}$ per kcal metabolizable energy, $4.5 \mathrm{~g}$ per kcal net energy. The piglets of treatment II had a mean intake of I I. $8 \mathrm{~g}$ Lysine per day. 